\title{
The Effect of Internal Marketing on Employee Job Satisfaction of Lion International Bank
}

\author{
Yonatan Zegeye Worede \\ Diploma in Accounting, Admas University College, from 2005 to 2007 \\ Degree in Economics, Bahir Dar University, from 2010 to 2013 \\ Degree in Accounting, St. Mary's University, from 2011 to 2015 \\ MBA in Accounting and Finance, St. Mary’s University, from 2014 to 2016
}

\begin{abstract}
The aim of the study was to examine the impact of internal marketing practices represented by the empowerment, training, leadership and motivation, on job satisfaction of $\mathrm{J}$ effect of internal marketing on employee job satisfaction of Lion International Bank. Internal marketing (IM) enhances the success of the marketing practices internally towards achievement of objectives. The satisfaction and retention of quality employees is an essential component of organizational success. Hence, the purpose of this study is to examine the effect of internal marketing on employees job satisfaction in Lion International Bank. Data were collected from 177 clerical employees through questionnaire based surveys to investigate the impact of internal marketing on employees' job satisfaction. The respondents were chosen using multistage sampling technique. The four internal marketing factors which are motivation, training and development, communication and empowerment were used in the questionnaire. After collecting the data, different statistical tests including descriptive statistics (mean and standard deviation), correlation and regression are applied using SPSS (statistical package for social science) version 21 software. . The results of the descriptive statistics indicated that the level of internal marketing practices is on average and there is a significant gap of internal marketing practices in Lion international bank. Moreover, the correlation analysis indicates that the overall IM practice has positive influence on employees' job satisfaction. Furthermore, the multiple regression result shows that except empowerment the three internal marketing factors which are training and development, communication and motivation have a statistically significant and positive impact on employees job satisfaction in Lion International Bank. The regression analysis of the model summery indicated that there are other factors in addition to the four internal marketing dimensions that determine the employee's job satisfaction in Lion International Bank. Therefore, Lion International Bank should try to make every effort to prioritize the important dimensions while practicing internal marketing activities so as to achieve the highest level of employees' job satisfaction.
\end{abstract}

Keywords: Internal marketing, Job satisfaction, Lion International Bank

DOI: $10.7176 / \mathrm{JMCR} / 63-02$

Publication date: December $31^{\text {st }} 2019$

\section{Introduction}

This chapter introduces the phenomenon under study. It consists of the background of the study, problem statement, research questions, objectives of the study, the importance of the study, scope of the study, limitation of the study. The chapter finally outlines the structure of the report.

\subsection{Background of the Study}

Banking has traditionally operated in a relatively stable environment for decades. However, today the industry is operating under new; more complex atmosphere resulted from the major changes in the economic and political conditions, and the storming effects of the financial crisis which the whole world is still recovering from. All these factors have forced the banks to find a new basis for competition in order to build and protect their competitive position. Most major banks have realized that improving service quality and creating customer relationships that deliver value beyond the provided by the core product itself is the key for fighting competition and driving performance.

Service marketing has highly evolved in to a highly competitive discipline with professionals and academics alike recognizing that many factors influence it and the ultimate success of service organizations. Due to the nature of the services, often the main determinant of a customer's perception of service quality is their interaction with the service staff (zeithmal and Bitner, 2009), leading organizations to acknowledge the importance of employees in service delivery and quality. Service organizations are less likely to provide high standards of service delivery if they do not ensure employee satisfaction (Glimore, 2003). Garicia, Valera, and Del Rio (2010) put forward that employee satisfactions and customer satisfaction are similar in that both require the provision of rewards to satisfy wants and needs and that in order to do so, organizations need to treat employees in much the same way as they would customers. This can be achieved by the application of internal marketing concepts in the organization. 
Internal marketing means that service firm must invest heavily in employee quality and performance. It must effectively train and motivate its customer-contact employees and all the supporting service people to work as a team to provide customer satisfaction (Kotler, 2014).

The concept of internal marketing has evolved from the original conceptualization of employee satisfaction/motivation by treating employees as customers and jobs as products for improving service quality (Sasser and Arbeit, 1980; Berry, 1981). The main concept of internal marketing is to make the employees as important as the external customers by treating them as internal customers (Grönroos, 1981). The importance of internal marketing lies in motivating the employees and encouraging them to offer super services to customers who will improve the customer satisfaction of the company's services (Lings and Greenly, 2005). The relationship between internal marketing and job satisfaction had been the concern of many researchers (Azzam, 2016; Braimah, 2016; Kukreja, 2017; Rajyalakshmi and Kameswari, 2009). So, it can be deduced that internal marketing has a strong correlation with employee job satisfaction.

Based on the above ideas and concepts, the study intended to investigate the extent of implementation of internal marketing practices represented by the empowerment, training and development communication and motivation and their effect on job satisfaction of Lion International Bank employees.

\subsection{Statement of the Problem}

Any organization to be successful there would be need for organizations to fulfill the needs of its employees. According to Kotler (2000), internal marketing should be as a priority before external marketing. Internal marketing Starts with the organization recruiting the right people in the position to reach the point where these employees are satisfied and willing to do their job and accomplish customer satisfaction.

According to naveed .A (2013) external customer satisfaction cannot be achieved without the fundamental contribution of the customer-contact employees who provide the service. The front-line employees of the bank interact with the majority of customers and generally handle a wide range of banking transactions. Because of the importance of the service provided, Bank firms should support customer-contact employees in order to acquire communicative sales skills and make them feel comfortable and satisfied with their job. The above ascertainment emerged the concept of Internal Marketing (IM). Since recent times internal marketing is proposing as a solution to the problem of delivering consistently high service quality.

According to Bouranta and Mavridoglou (2005), few empirical studies have been conducted regarding internal marketing and they attributed this to the lack of models demonstrating the significance of internal marketing among service firms. More recently, a study showed that banks suffer from weaknesses related to internal marketing, resulting from ineffective management in terms of interpersonal and technical skills (AlJaradi 2014). In the same line of argument, Alawi (2010) refers that the management in banks failed to comprehend employee needs because of poor channels of communication between management and employees.

In Ethiopia the need to banking services is increasing more than ever and people expect more and faster services from banks. Besides, service quality and customer satisfaction is becoming the slogan of all banks. But as one study conducted by Shanka (2012) inferior performance is observed in Ethiopian commercial banks in some important dimensions of service quality like responsiveness and empathy to customers. He concluded that this is may be due to lack of well organized and effective internal marketing within the bank system. So according to him in order to meet the increasing needs and expectations of customers the satisfaction of employees has to be first enhanced through specific and scientific relationship with internal marketing methods.

Studies had been conducted in different countries and service industries and shows that IM has a strong relationship with job satisfaction. For instance the study conducted in Jordan by suliman et'al(2003) showed that internal marketing practices have strongly influenced job satisfaction of commercial bank employees. The results of Kalid.A (2002) revealed that the internal marketing dimensions had a significant impact on the satisfaction level of employees of the National Bank of Egypt. Tahir .S. and Hummeyoun .N.(2013) also found a positive and strong association of bank employees satisfaction and internal marketing practice in pakistan. Furthermore, a study by Al-Borie (2012) examined the impact of internal marketing on job satisfaction of the teaching hospitals in Kingdom of Saudi Arabia. Marketing had a positive influence to nurses' job satisfaction (Peltire et al., 2008). So based on this empirical evidence done it is possible to argue that internal marketing is the reason for job satisfaction.

For the past many years lion international bank has taking initiative to satisfy employees so as to achieve the customer satisfaction. HRM policies have been formulated that are related to internal marketing. For instance, a range of training programmers' have been providing, job rotation every six month, salary increments, bonus and the like. Therefore, investigating the extent to which Lion International Bank is using internal marketing approach as a tool for execution of its strategic plan and its impact on the satisfaction of employees is of interest to the researcher. Thus, the intent of this study is to examine the extent of the internal marketing and its impact on employees' satisfaction in Lion International Bank.

On the basis of the above points this study assesses the extent of internal marketing practices and discover 
whether the internal marketing elements has had the intended strengthening effect on job satisfaction of employees of Lion International Bank.

\subsection{Research Question}

Based on the problems stated above, the research will address the following question.

* To explore the extent to which internal marketing is practiced in the Lion international bank

* To identify the degree of job satisfaction by the bank staff.

* To assess the relationship between internal marketing and job satisfaction

\subsection{Objectives}

\subsubsection{General Objectives}

Generally the research will find out to analyze the effect of internal marketing on employee job satisfaction of Lion International Bank.

\subsubsection{Specific Objectives}

To find the internal marketing practice of lion international bank

To determine as which impact of internal marketing on employee job satisfaction.

To find out the overall employee's job satisfaction.

\subsection{Research Hypotheses}

This study has the following hypotheses:

* Ha. There is significant and positive relationship between internal marketing and employees' job satisfaction

* Ha1.There is a positive and significant relationship between training and employees job satisfaction

* Ha2.There is positive and significant relationship between motivation and employees job satisfaction

* Ha3.There is a positive relationship between Empowerment and employees job satisfaction

* Ha4.There is a positive and significant relationship between communication and employees job satisfaction

\subsection{Scope of the Study}

The scope of this study is limited to internal marketing and job satisfaction by taking in to consideration the effects of various aspects of internal marketing on job satisfaction of employees from the view of employees of the lion international bank.

The study is confined to lion international bank in Addis Ababa branches. This is because of branches have a lot of customers and large amount of transaction, so in this branch there is load in work. As a result it's better to measure job satisfaction from the view point of internal marketing concepts in these types of branches as it can have major impact on the banks service delivery and customer satisfaction.

\subsection{Significance of the study}

The result of this study will have a contribution for Lion International Bank, other banks in Ethiopia, to the accumulated body of knowledge about internal marketing in general and other researchers who are interested in the area.

The study can help to clearly understand the role of internal marketing on employees' job satisfaction and the impact on service quality. As a result Officials of Lion International Bank can use it to take corrective actions on the areas having shortfalls by providing a justifiable guideline in designing internal marketing strategy development and other banks can use it for the designing and implementation of internal marketing in their organizations. In addition to this it can add to the internal marketing knowledge in general and services marketing in particular. Moreover, it will pave the way for academicians who are interested to make further investigation on the issue.

\subsection{Review of Related Literature}

\subsubsection{Training and development and job satisfaction}

Training and development is one of the most repetitively mentioned dimensions of Internal Marketing; Ahmed and Rafiq (2003), Gounaris (2006) and Tsai and Tang (2008) are among the scholars that identified training and development as one of the dimension internal marketing can be explained. According to Karen (2007), employee development is defined as a system for assisting employees to develop within their current jobs or advance to fulfill their goals for the future and different researchers defined job satisfaction as the extent of affective reaction to which frontline employees like their jobs. In the study conducted on the effect of employee development program on job satisfaction and employee retention by Karen (2007), Job satisfaction came from when employees are provided growth and development opportunities and when they are supplemented through 
fair and equitable human resource practices. All employees should be given equal opportunities for development if they each take ownership for their goals and action plans. It shows a clear link between training and job satisfaction, i.e. when people receive relevant and valuable training, they are generally happier in their jobs. When that training is carried to the next level and becomes overall development, employees tend to feel even more valued by their employers. They are not only given the tool to do their jobs well, but they are also given opportunities to develop new skills and attain career goals. Hence, the first hypothesis for this study here is a positive relationship between employee training and development and job satisfaction.

\subsubsection{Employee training and development and organizational commitment}

Organizational commitment is defined as an individual belief in and acceptance of the organization's goals and values and his or her willingness to exert considerable effort on behalf of the organization (Porter et al, 1973). Considerable work has shown that commitment to one's organization is usually accompanied by greater work motivation and a desire to make the firm more effective and prosperous as well as to exert visible effort beyond what is traditionally expected in their jobs (Mowday, et. al 1979).

Monetary rewards of individual skills is an important aspect of doing do not cause organizational commitment, rather employee business today and employee development will likely commitment with organization rely upon the opportunities grow in the future.

The benefits of employee given by the employer to conduct important, meaningful development extend beyond the actual skills gained and challenging work (Meyer \& Allen, 1977).

In the case study conducted on Employee's Belief regarding training benefit and Organizational commitment by (Amir et al, 2013), there is significant positive relationship between employee This study explored the relationship of organizational perception of training benefits and organizational commitment and employees' perception of training commitment.

\subsubsection{Communication and job satisfaction}

Communication is process whereby people within an organization give and receive messages, it is a vital prerequisite for a well-functioning internal marketing culture. Without people being able or prepared to communicate with each other, there will be no inter-departmental or inter functional co-ordination (Naude \& Murphy, 2003).

Researches indicate that internal communication is one of the factors which influence job satisfaction. With active and assessable communication, employees are better able to understand their job and are more connected to it. This leads to better performance and higher job satisfaction. Anderson and Martin (1995), Downs and Hazen, (1977), Madlock (2008), Orpen, (1997) and Varona, (1996) are among the researchers who studied the relation between communication and job satisfaction.

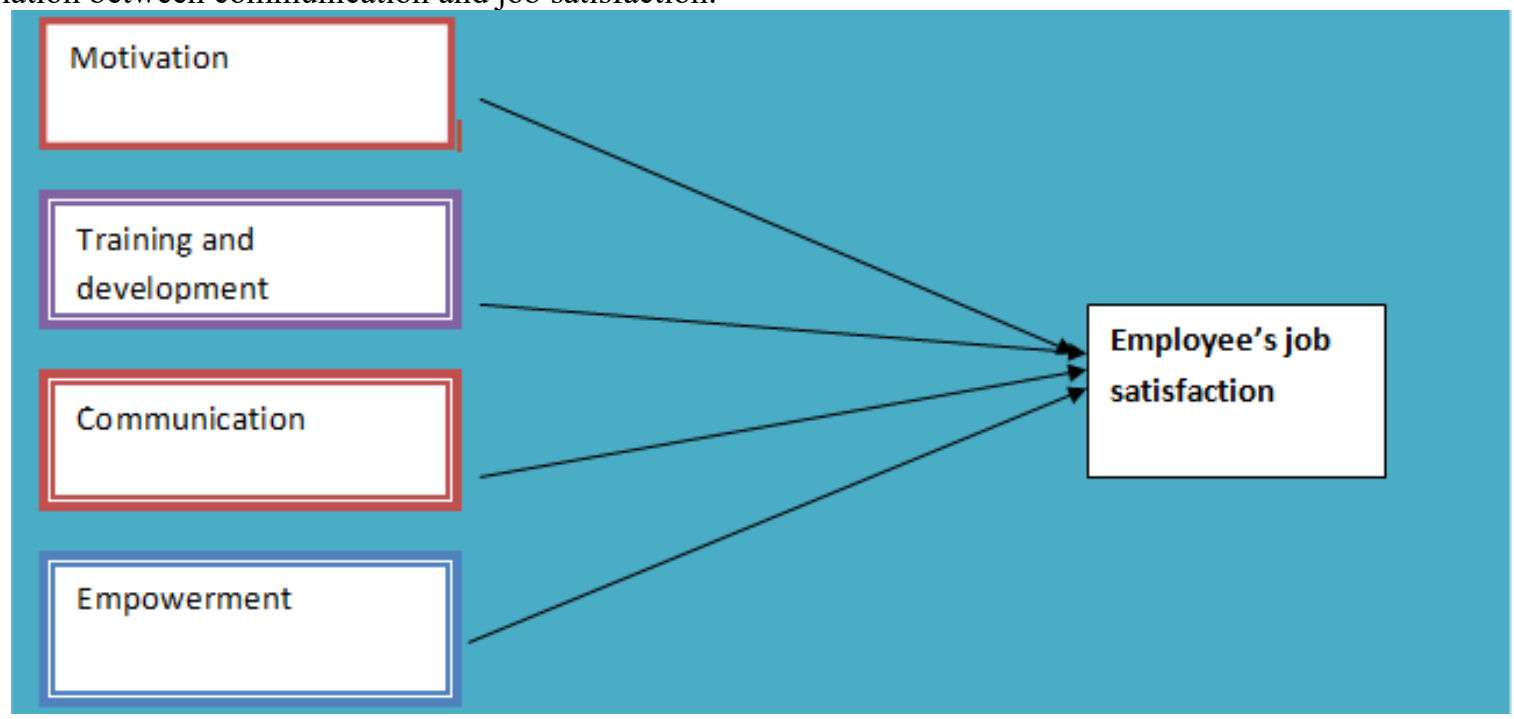

\subsection{Research Approach}

In the view to serve the research questions and objectives of the study, the researcher followed mixed research approach. Because, the researcher believed mixed methods of data analysis appropriate to correctly answerer the research questions under consideration, as it involves both qualitative and quantitative data in a study helps to triangulate the obtained information through both methods of data analysis (Creswell, 2009).Understating this, the study gave equal weight for both approaches rather than giving greater value for either of them the researcher followed pragmatism philosophy of knowledge claims, which is problem centered, pluralistic and real-world practice oriented instead of giving greater weight for either qualitative (post positivism) or quantitative 
(constructivism) approach. The development and perceived legitimacy of both qualitative and quantitative research in the social and human sciences, mixed methods research, employing the combination of quantitative and qualitative approaches, has gained popularity. This popularity is because research methodology continues to evolve and develop, and mixed methods is another step forward, utilizing the strengths of both qualitative and quantitative research. Also, the problem addressed by this finding is complex, and the use of either quantitative or qualitative approaches by themselves is inadequate to address this complexity. The inter-disciplinary nature of research, as well, contributes to the formation of research teams with individuals with diverse methodological interests and approaches.

\subsubsection{Research design}

A research design refers to the many ways in which research can be conducted to answer the question being asked. For example, descriptive research design is employed in those studies which are concerned with describing the characteristics of a particular individual, or of a group. It describes the nature of situation as it exists at the time of study as well as to explore the cause of particular phenomena (Kothari, 2004). Thus, since the purpose of this research is to examine the impact of internal marketing on job satisfaction of employees; descriptive research design is employed involving both descriptive and inferential statistics for analysis of some variables.

Studies might employ either quantitative or qualitative research approach or mixed approach. A quantitative research approach employs strategies of inquiry such as experiments and surveys, and collects information using preset standardized instruments that can generate relevant statistical data. As it involves measurements and systematic statistical analysis, this research used quantitative approach to achieve its purpose.

\subsubsection{Population and sample size}

\section{i. Targeted population}

The target population of the study was lion international bank workers' who recurrently working in Addis Ababa city administration

\section{ii. Sampling techniques}

Sampling is a technique, which helps to understand the parameters and for characteristics of the population by investigating only some part of it (Chandan, 1998). Appropriate sample size depends on various factors relating to the subject matter of the investigation like time, cost, degree of accuracy desired (Rangaswamy, 1995). But the sample size and the sample selection process procedure should assure the representativeness of the population. Sample size determination has its own scientific approach, but in this finding to determine the sample size, different factors such as research cost, time, and human resource, environmental condition, accessibility and availability of transport facilities were taken into consideration.

Concerning the techniques of sampling used, multistage sampling technique was employed. This is mainly because the research approach followed mixed methods.

Therefore, since there is a list of all units of the lion international bank in Addis Ababa city administration

Total sample population will take 200 from the population size of 401 . The sample size is calculated based on the formula Yamane (1967) provides a simplified formula to calculate sample sizes. A 95\% confidence level and $\mathrm{P}=0.05$ are assumed. $\mathrm{n}=\mathrm{N} /[1+\mathrm{N}$ (e) 2] Where $\mathrm{n}$ is the sample size, $\mathrm{N}$ is the population size, and e is the level of precision. $\mathrm{n}=\mathrm{N} /[1+\mathrm{N}$ (e) 2] (Ajays Singh,Micah B.Masuku).

$$
\begin{aligned}
& \mathrm{n}=\frac{\mathrm{N}}{1+\left(\mathrm{N}^{*} \mathrm{e} 2\right)} \quad \begin{array}{c}
\mathrm{n}=\text { sample population } \\
\mathrm{N}=\text { total population }
\end{array} \\
& \text { e2 }=\text { the desired level of precision } \\
& \mathrm{n}=1+\ldots \ldots *(0.05) 2 \\
& \mathrm{n}=\underline{\underline{200}}
\end{aligned}
$$

This refers to the number of items to be selected from the universe to constitute a sample. The size of sample should neither be excessively large, nor too small, It should be optimum. An optimum sample is one which fulfills the requirements of efficiency, representativeness, reliability and flexibility. While deciding the size of sample, researcher must determine the desired precision as also an acceptable confidence level for the estimate. The size of population variance needs to be considered as in case of larger variance usually a bigger sample is needed. The size of population must be kept in view for this also limits the sample size. The parameters of interest in a research study must be kept in view, while deciding the size of the sample. As such, budgetary constraint must invariably be taken into consideration when we decide the sample size (C.R kothari ,p56).

\subsubsection{Data source}

The data was collected from primary data source. Primary data source was collected through structured questionnaire. Structured questionnaire was developed and distributed to employees of selected lion international bank. 


\subsubsection{Definition of terms}

\section{* independent variables}

1. Training and Development: Designed activities from the environment that provides employees the opportunity from employers side with the purpose of enhancing the level to develop and learn new skills for their development of knowledge and skills or to modify the behaviors.

2. Communication: A general concept that covers the communication and feedback between executives and employees, horizontal and vertical communications, work related information and communication among departments.

3. Motivation: The development of desire within an employee to perform a task to his/her greatest ability based on that individuals own initiatives.

4. Empowerment : Empowerment has been described as a venue to enable employees make decisions and as a personal experience where individuals take responsibility for their own actions

\# Dependent Variables

1. Job Satisfaction: A set of favorable or unfavorable feelings and emotions with which employees view their work.

\subsubsection{DATA ANALYSIS}

The collected data was analyzed by using STATA version 16 Software both descriptive and econometrics model (ordered job satisfaction regression model) was used to know the effect of internal marketing on employees' customer orientation the selected commercial banks. Regression analysis was used to know by how much the independent variable i.e. relationship marketing explains or influences the dependent variable which is employees' job satisfaction.

Correlation analysis also conducted to measure the strength of the association between relationship internal marketing (training and development, communication, motivation and Empowerment) and employee's job satisfaction. And also descriptive analysis used for the demographic factors such as gender, age, education and work experience. Tools like tables and percentage was used.

In order to reduce the possibility of getting wrong answers, different actions were taken to ensure the soundness of data.

1. Data was collected from reliable sources, from respondents who are employees 'of the bank.

2. The questionnaire was based on literature review to ensure the soundness of the results.

3. STATA software version 16 was used to analyze the data and special emphasis was given during data encoding.

\subsection{DATA PRESENTAION, ANALYSIS AND INTERPRETATION}

\subsubsection{Introduction}

This chapter presents the findings from data analysis and is divided into five sections. Section 4.2 presents results from pilot study and descriptive statistics, section 4.3 presents frequency for firm internal marketing and job satisfaction, section 4.4 presents results for factor analysis and section 4.5 presents regression results and their interpretation

\subsubsection{Demographic background of the respondents}

\subsubsection{Educational qualification of respondents}

Response was obtained from 177 employees of different companies $65 \%$ of the respondent is bachelor degree and $35 \%$ of the respondent have hold master degree. Its implies that the respondents have sufficient knowledge on internal marketing and job satisfaction and the responses they provide to be valid 


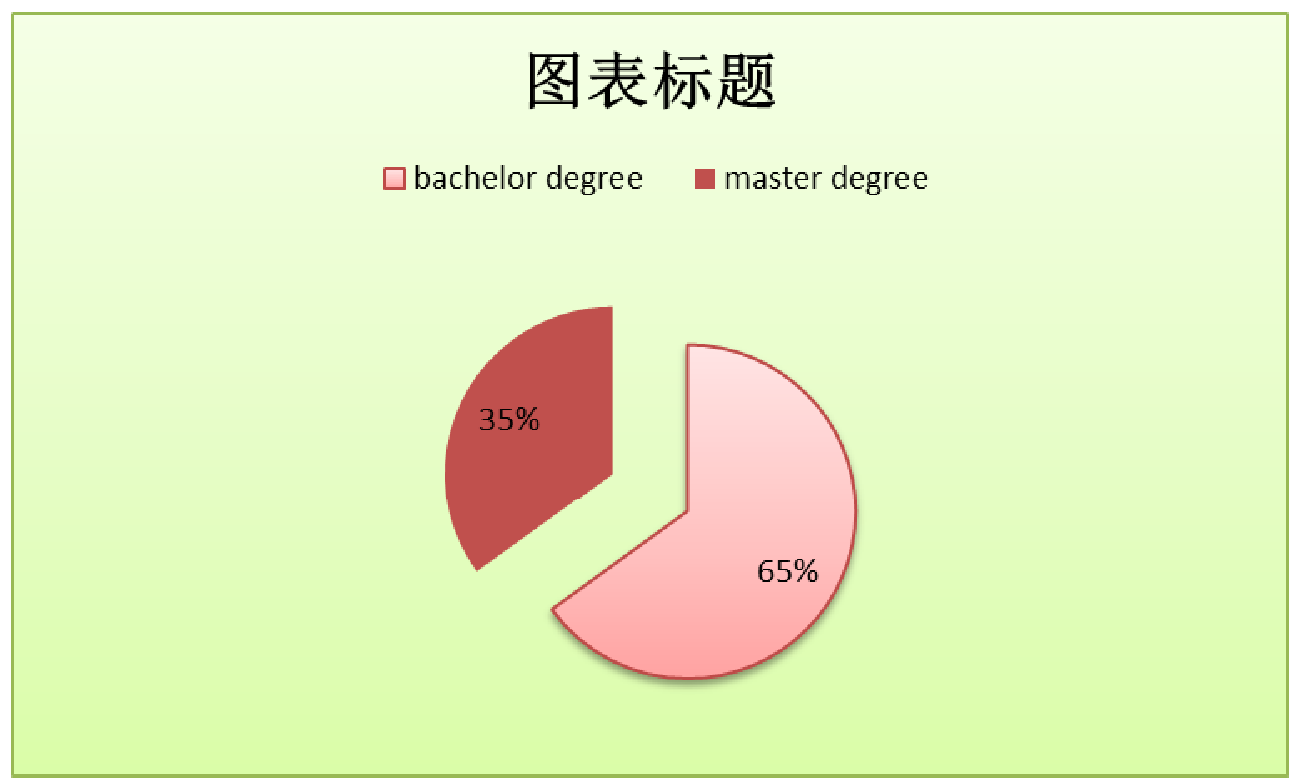

1.10.4. Working experience

Considering the age groups of the respondents, the higher number of respondents was in the range of 5-10 years, which represent $39 \%$, followed by age groups of $11-15$ years and less that 5 years which represent $27 \%$ and $20 \%$ respectively.

\begin{tabular}{ccc}
\hline DESCRIPTION & Frequency & \% \\
\hline $\mathbf{1 1 - 1 5}$ years & 27 & $27 \%$ \\
$\mathbf{1 6 - 2 0}$ years & 10 & $10 \%$ \\
5-10 years & 39 & $39 \%$ \\
less than 5 years & 20 & $20 \%$ \\
More than 20 years & 4 & $4 \%$ \\
Total & 100 & $100 \%$ \\
\hline
\end{tabular}

1.10.5. Gender of the respondents

Table 3: Gender of the respondents

\begin{tabular}{|c|l|l|l|l|}
\hline & Frequency & Percent & Valid Percent & Cumulative Percent \\
\hline Gender & 128 & 72.3 & 72.3 & 72.3 \\
Fale & 49 & 27.7 & 27.7 & 100.0 \\
Total & 177 & 100.0 & 100.0 & \\
\hline
\end{tabular}

\section{Source: SPSS output}

Regarding gender of the respondents, majority $(72 \%)$ of the respondents were male while $28 \%$ of the respondents were female (table3). This suggests a fair representation of gender thereby the study collected views from both genders.

\subsubsection{Pilot Study Results}

The study conducted pilot study to test the reliability and validity of the research instrument. The study used 10 percent of the lion international bank employees for pilot testing. Consequently, 10 percent of 200 translated into approximately 10 the bank employee. The study used random sampling to select 10 officers and manager of who were not included in the main survey.

With the exception of demographic characteristics, other variables were measured as construct. These variables had several items that measured the same concept or phenomenon. Thus this study tested for reliability based on the Cranach's alpha values for each measurement construct and then for the overall items used in the 177 questionnaire. The reliability results for each measurement construct are presented in table. The result shows that the Cranach's alpha for Job satisfaction constructs is 0.757 with a total of 9 items. This implies that the items included in Job satisfaction are indicative of the same underlying disposition. The Cranach's alpha for Motivation, Training and development, Communication and Empowerment variables were 0.742, 0.878, 0.930 and 0.942 respectively implying that the items in the construct are indicative of the same underlying disposition.

The Cronbach 's alpha for Job satisfaction construct is 0.757 with a total of 9items implying that the items included are a good indicative of the same underlying disposition. The value of the Cronbach ' $\mathrm{s}$ alpha for all measurement constructs is greater than or equal to the 0.7 value implying that the research instrument is reliable. 
Table 4

\begin{tabular}{|l|l|l|}
\hline Variable & Number of Items & Cronbach's Alpha \\
\hline Motivation & 5 & 0.742 \\
Training and development & 6 & 0.878 \\
Communication & 5 & 0.93 \\
Empowerment & 4 & 0.942 \\
Job satisfaction & 9 & 0.757 \\
\hline
\end{tabular}

\section{Source: SPSS output}

\subsubsection{Descriptive Analysis of variable}

Motivation provides the link between plans and action. Employees must know the expectation of their organization. From the above table $68.9 \%$ of the respondents had used Motivation in very great extent way while $19.8 \%$ of the respondent had used the Motivation not at all and $11.3 \%$ is neural. From these we can say that the motivation among the employees of lion bank were extreme.

\section{Motivation}

\begin{tabular}{|c|c|c|c|c|c|}
\hline & & Frequency & Percent & Valid Percent & Cumulative Percent \\
\hline \multirow{6}{*}{ Valid } & 1.00 & 4 & 2.3 & 2.3 & 2.3 \\
\hline & 2.00 & 31 & 17.5 & 17.5 & 19.8 \\
\hline & 3.00 & 20 & 11.3 & 11.3 & 31.1 \\
\hline & 4.00 & 52 & 29.4 & 29.4 & 60.5 \\
\hline & 5.00 & 70 & 39.5 & 39.5 & 100.0 \\
\hline & Total & 177 & 100.0 & 100.0 & \\
\hline
\end{tabular}

\section{Table 5}

\section{Source: SPSS output}

One of the methods to assess job satisfaction in selected lion bank analyzed training and development method. There were six question presented to evaluate Training and development methods. Regarding the first question, the response showed that from the above table $68.4 \%$ of the respondents had beloved Training and development in very great extent way while $7.7 \%$ and $20.9 \%$ of the respondent had used the Training and development not at all and $20.9 \% \%$ is neural. From these we can say that the Training and development among the employees of lion bank were extreme agree. The respondent have the organization views the development of Knowledge and skills in employees as an investment rather than a cost.

Training

\begin{tabular}{|c|c|c|c|c|c|}
\hline & & Frequency & Percent & Valid Percent & Cumulative Percent \\
\hline \multirow{6}{*}{ Valid } & 1.00 & 8 & 4.5 & 4.5 & 4.5 \\
\hline & 2.00 & 11 & 6.2 & 6.2 & 10.7 \\
\hline & 3.00 & 37 & 20.9 & 20.9 & 31.6 \\
\hline & 4.00 & 63 & 35.6 & 35.6 & 67.2 \\
\hline & 5.00 & 58 & 32.8 & 32.8 & 100.0 \\
\hline & Total & 177 & 100.0 & 100.0 & \\
\hline
\end{tabular}

Table 6

Source: SPSS output

From the table $71.8 \%$ of the respondents had used Communication in very great extent way while $28.2 \%$ of the respondent had used the Communication not at all. From these we can say that the Communication among the employees of lion bank were extreme.

\begin{tabular}{|c|c|c|c|c|c|}
\hline \multicolumn{6}{|c|}{ Communication } \\
\hline & & Frequency & Percent & Valid Percent & Cumulative Percent \\
\hline \multirow{5}{*}{ Valid } & 1.00 & 16 & 9.0 & 9.0 & 9.0 \\
\hline & 2.00 & 34 & 19.2 & 19.2 & 28.2 \\
\hline & 3.00 & 101 & 57.1 & 57.1 & 85.3 \\
\hline & 4.00 & 26 & 14.7 & 14.7 & 100.0 \\
\hline & Total & 177 & 100.0 & 100.0 & \\
\hline
\end{tabular}

\section{Table 7}

\section{Source: SPSS output}

From the table $50.3 \%$ of the respondents had used empowerment in very great extent way while $49.7 \%$ of the respondent had used the Communication not at all. From these we can say that the Communication among the 
employees of lion bank were extreme.

\begin{tabular}{|c|c|c|c|c|c|}
\hline \multicolumn{6}{|c|}{ Empowerment } \\
\hline & & Frequency & Percent & Valid Percent & Cumulative Percent \\
\hline \multirow{6}{*}{ Valid } & 1.00 & 11 & 6.2 & 6.2 & 6.2 \\
\hline & 2.00 & 77 & 43.5 & 43.5 & 49.7 \\
\hline & 3.00 & 63 & 35.6 & 35.6 & 85.3 \\
\hline & 4.00 & 22 & 12.4 & 12.4 & 97.7 \\
\hline & 5.00 & 4 & 2.3 & 2.3 & 100.0 \\
\hline & Total & 177 & 100.0 & 100.0 & \\
\hline
\end{tabular}

\section{Table 8}

\section{Source: SPSS output}

From the table $52.5 \%$ of the employee's Job satisfaction and very great extent way while $13.6 \%$ of the respondent had used the Job satisfaction not at all. From these we can say that the Job satisfaction among the employees of lion bank were extreme.

Job satisfaction

\begin{tabular}{|c|c|c|c|c|c|}
\hline & & Frequency & Percent & Valid Percent & Cumulative Percent \\
\hline \multirow{5}{*}{ Valid } & 1.00 & 24 & 13.6 & 13.6 & 13.6 \\
\hline & 2.00 & 60 & 33.9 & 33.9 & 47.5 \\
\hline & 3.00 & 60 & 33.9 & 33.9 & 81.4 \\
\hline & 4.00 & 33 & 18.6 & 18.6 & 100.0 \\
\hline & Total & 177 & 100.0 & 100.0 & \\
\hline
\end{tabular}

\section{Table 9}

\section{Source: SPSS output}

\subsubsection{Inferential Statistics Analysis}

Correlation and Multiple regression analysis were conducted by using SPSS in order to examine the effects of aspects of internal marketing on employees' satisfaction.

\subsubsection{Diagnosis Tests}

\subsubsection{Normality Test}

As it can be seen from figure, although there are some residuals (e.g., those occurring around 0) that are relatively far away from the curve, many of the residuals are fairly close. Moreover, the histogram is bell shaped which lead to infer that the residual (disturbance or errors) are normally distributed. Thus, no violations of the assumption normally distributed error term.

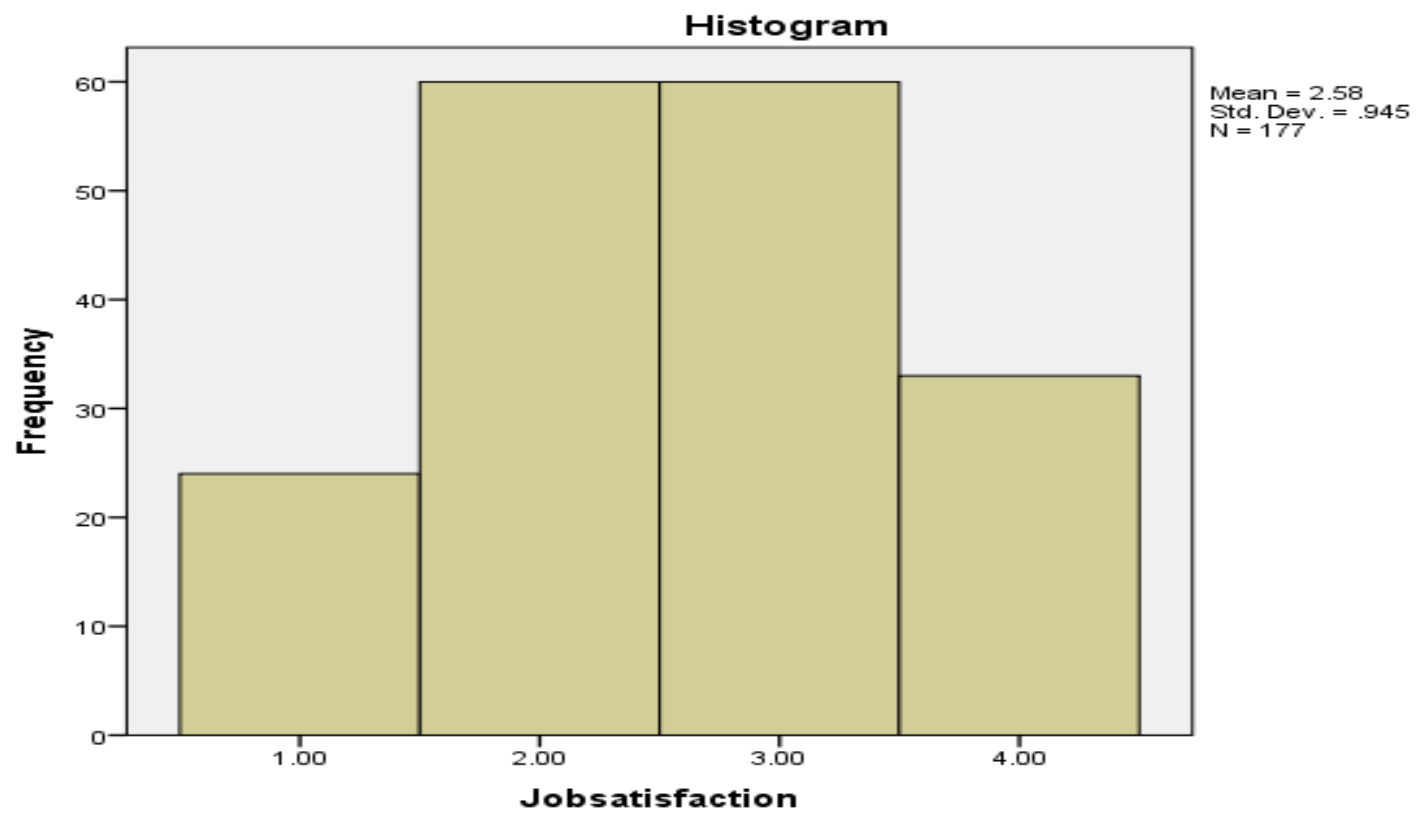

\section{Source: SPSS output}

\subsubsection{Autocorrelation Tests}

According to Brooks (2008), the covariance between the error terms over time (or cross sectional, for that type 
of data) is zero. That means, it is assumed that the errors are uncorrelated with one another. If the errors are not uncorrelated with one another, it would be stated that they are auto correlated or they are serially correlated.

To test the presence of autocorrelation, the Durbin Watson test is used. As noted in Brooks (2008), Durbin Watson is a test for first order autocorrelation (it is a test for a relationship between an error and its immediate previous value). If the Durbin Watson test approaches to two, it is an indication of the absence of autocorrelation.

This assumption stated that the covariance between the error terms over time (or cross sectionals, for that type of data) is zero. In other words, it is assumed that the errors are uncorrelated with one another. If the errors are not uncorrelated with one another, it would be stated that they are auto correlated or that they are serially correlated (Brooks, 2008).

To test the presence of autocorrelation, the Durbin Watson test is used. As noted in Brooks (2008), Durbin Watson is a test for first order autocorrelation (it is a test for a relationship between an error and its immediate previous value). If the Durbin Watson test approaches to two, it is an indication of the absence of autocorrelation. As per Brooks (2008) lagged the value is simply the value that the variable took during a previous period. In this study the Durbin Watson test of so from the regression result DW is 1.783 it is very close to two. The test indicates that the absence of autocorrelation which show the absence of autocorrelation problem.

Table 10 Durbin-Watson - statistic test

\subsubsection{Multicollinearity Test}

As referred by Brooks (2008), an implicit assumption that is made when using the OLS estimation method is that the explanatory variables are not correlated with one another. If there is no relationship between the explanatory variables, they would be said to be orthogonal to one another. However, a problem occurs when the explanatory variables are very highly correlated with each other, and this problem is known as multicollinearity.

Malhotra (2007) stated that multicollinearity problems exists when the correlation coefficient among explanatory variables should be greater than 0.75. However, Brooks (2008) mentioned that if the correlation coefficient along with the independent variables is 0.8 and above, multicollinearity problems will exist.

The method used in this study to test the existence of multicollinearity was by checking the Pearson correlation between the independent variables. The correlations between the independent variables are shown in table above. All correlation results are below 0.75 , which indicates that multicollinearity is not a problem for this study.

\begin{tabular}{|c|c|c|c|c|c|c|}
\hline \multirow{5}{*}{ 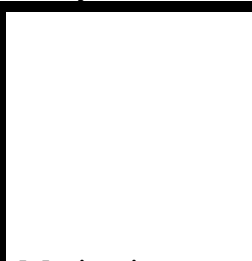 } & +2 & \multicolumn{3}{|c|}{.Correlations } & \multirow[b]{2}{*}{ Empowerment } & \\
\hline & & Motivation & Training & Communication & & $\begin{array}{c}\text { Job } \\
\text { satisfaction }\end{array}$ \\
\hline & Pearson & & & & & \\
\hline & Correlation & 1 & & & & \\
\hline & Sig. (2-tailed) & & & & & \\
\hline \multirow[t]{4}{*}{ Motivation } & $\mathrm{N}$ & 177 & & & & \\
\hline & Pearson & & & & & \\
\hline & Correlation & $.378^{* *}$ & 1 & & & \\
\hline & Sig. (2-tailed) & 0 & & & & \\
\hline \multirow[t]{4}{*}{ Training } & $\mathrm{N}$ & 177 & 177 & & & \\
\hline & Pearson & & & & & \\
\hline & Correlation & $.472^{* *}$ & $.255^{* *}$ & 1 & & \\
\hline & Sig. (2-tailed) & 0 & 0.001 & & & \\
\hline \multirow[t]{4}{*}{ Communication } & $\mathrm{N}$ & 177 & 177 & 177 & & \\
\hline & Pearson & & & & & \\
\hline & Correlation & $.308^{* *}$ & 0.14 & $.685^{* *}$ & 1 & \\
\hline & Sig. (2-tailed) & 0 & 0.062 & 0 & & \\
\hline \multirow[t]{4}{*}{ Empowerment } & $\mathrm{N}$ & 177 & 177 & 177 & 177 & \\
\hline & Pearson & & & & & \\
\hline & Correlation & $.390^{* *}$ & $.556^{* *}$ & $.528^{* *}$ & $.533^{* *}$ & 1 \\
\hline & Sig. (2-tailed) & 0 & 0 & 0 & 0 & \\
\hline Jobsatisfaction & $\mathrm{N}$ & 177 & 177 & 177 & 177 & 177 \\
\hline
\end{tabular}

As depicted in the above table the Pearson Correlation between job satisfaction and the four components of internal marketing i.e. motivation, communication, training and development and empowerment presents positive values as well as statistically significant. Thus internal marketing components and job satisfaction has positive relationship. Training and development has strong correlation $(\mathrm{r}=.472)$ with job satisfaction followed by motivation $(\mathrm{r}=.378)$, empowerment $(\mathrm{r}=.390)$ and communication $(\mathrm{r}=.308)$ respectively. The correlation values are 
above 0.5 which is strong according to (Cohen, 1988, cited in Pallant, 2007, p.132).

\subsubsection{Results of Regression Analysis}

The first regression analysis was undertaken to investigate the relationship job satisfaction system between independent variable by using simple linear regression model we can explain the extent to which significantly affect by the variable

Coefficients $^{\mathrm{a}}$

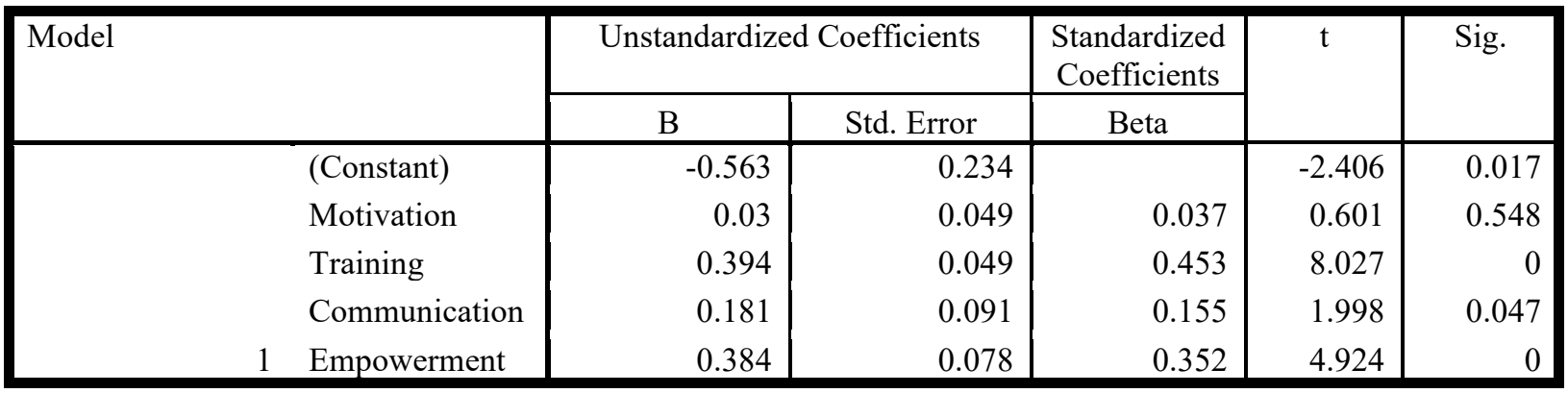

a. Dependent Variable: Job satisfaction Source: SPSS output

\begin{tabular}{|r|r|r|r|r|r|}
\hline Model & R & R Square & $\begin{array}{c}\text { Adjusted R } \\
\text { Square }\end{array}$ & $\begin{array}{c}\text { Std. Error } \\
\text { of the } \\
\text { Estimate }\end{array}$ & $\begin{array}{c}\text { Durbin- } \\
\text { Watson }\end{array}$ \\
\hline 1 & $.732 \mathrm{a}$ & 0.535 & 0.525 & 0.65166 & 1.783 \\
\hline
\end{tabular}

a. Predictors: (Constant), Empowerment, Training, Motivation, Communication

b. Dependent Variable: Job satisfaction

Job satisfaction $=0.563+0.03$ Motivation+0.394 Training+0.181 Communication+0.384 Empowerment

The regression Analysis result shows R-squared statistics and adjusted R squared statistics value of $73.2 \% \%$ and $53.5 \%$ respectively. The result indicates that the change in the independent variable explain $53.5 \%$ of the change in the dependent variable. That is Motivation, Training and development, Communication , Empowerment explains $53.5 \%$ of Job satisfaction.

Based on the result of Table the coefficient of Motivation, Training and development, Communication, Empowerment were $0.03,0.394,0.181$ and 0.384 respectively. This indicates a positive relationship with internal marketing. This reveals that there is a direct relationship between job satisfaction and internal marketing and statistically significant.

\subsubsection{Discussion of the Results}

This paper is aimed to examine the impact of internal marketing in its four components; training and development, motivation, communication and empowerment on employees Job satisfaction in Lion international bank. In this section detail discussions are done based on regression results presented in the previous Table 4.4.3.1. The empirical findings are combined with the theory and other similar research findings in order to provide a wider perspective.

1.10.15. Training is positively and significantly related to employee's job satisfaction.

The results of the study show that training has significant and highest impact on employees satisfaction in Lion international bank. Recently many researchers are studying extensively the effect of training and development as a dimension for employee's job satisfaction and how the job training does and development related to job satisfaction. Because the organization is aware that its most valuable asset they have is the human resource, and because the company seek forward higher service quality and improved performance, thus they organized a training and development programs for its employees in order to improve their performance and capabilities through investing to have a skilled, powerful, unique, high service performance (individually or team) and greater knowledge in different required field even though the organization is aware about the high cost of this programs but the know that the returned of this method will recover their the cost of it and also with a good return compensated later on. To be effective, training and management development programs need to take into account that employees are adult learners (Forrest \& Peterson, 2006). Obisi (1996) submitted that training and development aim at developing competences such as technical, human, conceptual and managerial for the furtherance of individual and organization growth.

1.10.16. Motivation is positively and significantly related to employee's job satisfaction.

One of the research findings that can be concluded from the statistics provided above is that motivation is positively related to and significant effect on employee's job satisfaction in Lion international bank. This result is also consistent with Ahmad et al. (2012) finding of the positive correlation between motivation and job 
satisfaction.

\subsubsection{Empowerment is positively related to employee's job satisfaction.}

Participation is a process by which influence is shared among individuals who are otherwise hierarchical unequal (Locke and Schweiger, 1979; Wagner, 1994). Empowerment has been described as a venue to enable employees make decisions (Bowen \& Lawler, 1992) and as a personal experience where individuals take responsibility for their own actions. There is a participatory management that manages the subordinate participation in decision making process ,taking actions, and solving any problems or conflicts during job in logical way that fits the organization objectives and the creativity components is very important for employees to develop a new means to implement their tasks and in cases including risks, Berry and Parasuraman (1991) also regard empowerment as an essential aspect of IM. Empowerment or in other words participation of front-line employees in making decisions related to their routine job activities is directly related to job satisfaction, previous researchers have highlighted the significant relationship between empowerment and job satisfaction (e.g. Spreitzer, 1996 \& George, 2003). However, empowerment has positively correlated with job satisfaction the multiple regression result does not indicated a significant impact on Lion international bank employees satisfaction.

\subsubsection{Communication is positively related to employee's job satisfaction.}

Regarding to Communication as the above statistics imply, communication has a positive relationship and it has significant impact on job satisfaction of Lion international bank employees.. According to Tourani et al. (2012) many researchers assert that communication in organization has significant effect on employees' job satisfaction. Results from the analysis also showed that communication is significantly related and in fact contributes to employee satisfaction. This result is in tandem with Al-Hawary et al. (2013) who reported that communication had a positive relationship with job satisfaction. Also, Marty (2014) confirmed that increases in open channel communication with employees will be followed by increases in employee satisfaction.

\subsection{1. summary, conclusion and recommendation}

\subsubsection{Introduction}

This chapter of the research paper includes summary of the results of the research (findings), conclusion and recommendations.

\subsubsection{Summary of findings}

The research examined the effect of internal marketing on employee job satisfaction of Lion International Bank. The study revealed the following important findings that were derived from quantitative and qualitative analysis: in line with the objective of this research the effect internal marketing on employee job satisfaction of Lion International Bank, the researcher has adopted questionnaires to gather firsthand information from the respondents with heterogeneous age bracket, level education, field of study, and service period. Then, reliability and validity test was conducted in order to check the inconsistency of the data. As the validity was enhanced through discussion of the questionnaire contents of employees worked in Lion International Bank. The reliability was tested through statistical package for social sciences (SPSS) and Cronbach alpha correlation coefficient was used to satisfy the reliability tests. The result shows 0.757 for Job satisfaction constructs with a total of 9 items. For Motivation, Training and development, Communication and Empowerment constructs Cronbach alpha results were $0.742,0.878,0.930$ and 0.942 respectively. The study had 200 questionnaires distributed and from those questionnaires 177 were collected and returned for analysis.

Taking the regression and correlation results the study revealed positive and significant relationship between overall internal market practices and employee job satisfaction. This put forwards that internal market orientation and employee job satisfaction are associated with each other. In this study, training and development is found to be a major indicator of employee's satisfaction followed by communication and motivation. However, as indicated by the regression results empowerment does not have a significant impact on satisfaction of employees of Lion International Bank. The regression result revealed that only $53.5 \%$ of the variance in job satisfaction has been significantly explained by the four dimensions of internal market orientation. This shows that besides these internal marketing dimensions, there are other important variables which lead to satisfaction of Lion International Bank clerical employees.

\subsubsection{Conclusions}

The prime purpose of the research was to analyze the relationship between internal marketing practices and employee job satisfaction. This research has fulfilled the objectives as a mentioned earlier above. The first objective was to analyze the relationship between internal marketing practices and job satisfaction which revealed a positive relationship. This proves that internal market orientation and employee job satisfaction was connected with each other. The second objective is to identify the relationship between training and development and employee's job satisfaction. Finding dictates that there was a significant relationship. The third objective was to find out the relationship between organizational support and employee's job satisfaction. The finding reveals that there is positive correlation between organizational support and employee job satisfaction. Another objective was to examine the relationship between pay and rewards and employee's job satisfaction. The 
findings depicted that there is a positive relationship between them. The regression result shows that the pay and rewards are the most important factor to evaluate the employee's job satisfaction in the retail sector in Lion International Bank. In conclusion, this research has successfully attended the four research objectives and proved that internal marketing is positively related with employee job satisfaction.

\subsubsection{Recommendations}

External customer satisfaction is the mirror image of internal customer satisfaction. Based on the analysis and conclusions made the following recommendations are forwarded with the intention that they enhances job satisfaction of employees in Lion International Bank if applied to the real world scenario.

In Lion International Bank the satisfaction of clerical employees shows a big gap. Therefore, the bank should undertake need assessment program to identify the unfulfilled needs and try to refill these needs of its internal customers.

The regression analysis made highlighted the relative importance of the internal marketing dimensions. This can be used as in indicator to identify which area to focus on while dealing with application of internal marketing concept. According to the result of the regression analysis three dimensions are found to be positively and statistically affecting employees' job satisfaction. As a result the bank is advised to undertake the following in this regard.

Arrange both on job and off job training programs especially when new employees are hired, new technologies are introduced or when new means and methods of operation are applied. Also, management should offer new training programs to all departments and employees. This is to help keep the employees abreast with latest developments in the financial business, and for the acquisition of knowledge, skills, attitudes, and other performance-based indicators. Additionally, these practices help to motivate employees an opens up new opportunities on their career development. It is this important that management believe in listening to its employees, buy into their opinions and build the trust with them. This is an important means of satisfying employees in Lion International Bank. This helps the bank to have an excellent differentiation. Because as indicated in different literatures it cannot be duplicated. Everything else can be duplicated, despite all best efforts to protect intellectual property. However no one can ever duplicate the workforce because it is unique, it forms a culture and a face to a business.

Lion International Bank management should develop their strategies taking into cognizance the intrinsic and extrinsic benefits such strategies will be to employees, and specifically making these strategies more effective in the form of bonuses, monetary rewards and recognition. The bank should develop and apply different motivational factors both financial (e.g. attractive salary, fringe benefits) and non-financial (e.g. recognition, job security, promotion, participation in decision making etc) to employees satisfaction.

To put in one basket, if Lion International Bank wants to ultimately provide better service experience for its customers, it is recommended that more attention be directed toward enhancing job satisfaction among personnel, with a focus on training and development, communication, and motivation.

\section{References}

Ahmed, K.P. and Rafiq, M. (1995). The role of internal marketing in the implementation of marketing strategies. Journal of Marketing Practice: Applied Marketing Science vol. 1(4), 32-51.

Ahmed, P. K. and Mohammed Rafiq. (2003).'Internal marketing issue and challenge, European Journal of Marketing, Vol. 37 No.9, pp.1177-86.

Ahmed, P.K and Rafiq, M. (2000). "Advances in the internal marketing concept: definition, synthesis and extension", Journal of Services Marketing, Vol. 14 No. 6, pp. 449-6

Ahmed, P.K., Rafiq, M. and Saad, N.M. (2003). "Internal marketing and the mediating role of organizational competencies”, European Journal of Marketing, Vol. 37 No. 9, pp. 1221-41.

Al-Hawary, S. I. S., Al-Qudah, K. A., Mash"eal Abutayeh, P., Mash"eal Abutayeh, S., \& Al-Zyadat, D. Y. (2013). The impact of internal marketing on employee es job satisfaction of commercial banks in Jordan. Interdisciplinary Journal of Contemporary Research in Business, 4(9), 811-826.

Arnett, D., Laverie, D., McLane, C. (2002). "Using Job Satisfaction and Pride as Internal -Marketing Tools". Cornell Hotel and Restaurant Administration Quarterly, April : 88-96.

Ballantyne, D. (1997). "Internal networks for internal marketing", Journal of Marketing Management, 13: 343366.

Ballantyne, D. (2003) A Relationship-mediated Theory of Internal Marketing. European Journal of Marketing, 37(9), pp. 1242-1260.

Ballantyne, D., Christopher, M. \& Payne, A. (1995). Relationship marketing: bringing quality, customer service and marketing together, Oxford: Butterworth Heinemann/Centre for Services Management, Cranfield School of Management

Barnes, J.G. (1998) Relationship marketing and sustained competitive advantage. Journal of Market Focused Management 2, 281-97. 
Barnes, J. G. (1989) The role of internal marketing: if the staff won't buy it why should the customer?. Irish Marketing Review, 4(2), pp. 11-21.

Bansal, H. S., Mendelson, M. B., \& Sharma, B. (2001). The impact of internal marketing activities on external marketing outcomes. Journal of Quality Management, 6(1), 61-76.

Berry, L. (1981). “The Employee as Customer”, Journal of Retail Banking, Vol. 3, pp. 25-28.

Berry, L. L. (1980). "Services Marketing is Different”, Business, May- June, pp.24- 30

Berry, L.L. and Parasuraman, A. (1991). Marketing services, competing through quality, The Free Press, New York, NY.

Berry, L.L., Hensel, J.S. and Burke, M.C. (1976). "Improving retailer capability for effective consumerism response", Journal of Retailing, Vol. 52 No. 3, pp. 3-14.

Berry, L.L. (1984). The employee as customer, in Lovelock, C. (Ed.), Services Marketing, Kent Publishing, Boston, MA,272-8.

Bitner, M.J., Booms, B.H. and Tetreault, M.S. (1990). "The service encounter: diagnosing favorable and unfavorable incidents", Journal of Marketing, Vol. 54, pp. 71-84.

Bitner, M., Ostrom, A., \& Meuter, M. (2002). Implementing successful self-service technologies. Academy of Management Executive, 16 (4), 96-107.

Borden, N., (1964). The concept of marketing mix. Journal of Advertising, 4, 2-7.

Bowen, D.E., \& Lawler, E.E. (1992). "The empowerment of service workers: What, why, how and when", Sloan Management Review, Vol. 33 No. 3, pp. 31-39.

Broussard, S. C., \& Garrison, M. E. B. (2004). The relationship between classroom motivation and academic achievement in elementary school-aged children. Family and Consumer Sciences Research Journal, Vol.33, No.2, pp.106-120.

Cahill, D. (1995) The managerial implications of the new learning organisation: a new tool for internal marketing. Journal of Services Marketing, 9(4), pp. 43-51.

Caruana, A. and Calleya, P. (1998). "The effect of internal marketing on organizational commitment among retail bank managers", International Journal of Bank Marketing, Vol. 16 No. 3,pp. 108-116.

Ching-sheng Change, H. and Hsin-Hsin Change (2007). "Effect of Internal Marketing on Nurse Job Satisfaction and Organizational commitment: Example of Medical Center in Southern Taiwan", Journal of Nursing Research, Vol. 15 No.4.

Collins, B. and Payne, A. (1991). Internal Marketing: A New Perspective for HRM. European Management Journal 9 (3): 261-70

Collis, J. and Hussey, R. (2003) Business Research A practical guide for undergraduate and postgraduate students, Second Edition, Basingstoke, Hampshire: Palgrave Macmillan.

Conduit, J. and Mavondo, F. (2000) Internal customer orientation: What it is and what it is not. Marketing in a Global Economy, American Marketing Association International Marketing Conference, Buenos Aires, Argentina, (June 28-July 1).

Conduit, J. and Mavondo, F. (2001) How Critical is Internal Customer Orientation to Market Orientation? Journal of Business Research, 51(1), pp. 11-24.

Efthymios, Iliopoulos and Constantinos-Vasilios Priporas (2011). "The effect of internal marketing on job satisfaction in health services: a pilot study in public hospitals in Northern Greece", BMC Health Serv Res., Vol. 11, p. 261.

Foreman, S. K. and Woodruffle, H. (1991). Internal Marketing: A Case for Building Cathedrals. Proceeding of the Annual Conference of the Marketing Education Group, Cardiff Business School, 404-421.

Forrest III, S. \& Peterson, T. (2006). "It's called andragogy", Academy of Management Learning and Education, Vol. 5 No. 1, pp.113-122.

Garcia ,T. ,Varela. J. and Dell Rio, M.( 2010). Organizational service systems: antecedents and consequences .tourism and hospitality research, 11(1):67-82

George, W. R.(1977). The Retailing of services: a challenging future. Journal of Retailing Outono, p. 85-98

George,W.R. (1990), "Internal marketing and organizational behavior: a partnership in developing customerconscious employees at every level", Journal of Business Research, Vol. 20, pp. 63-70.

George, W. R. \& Gronroos, C. 1990. Developing Customer-Conscious Employees At Every Level-Internal Marketing. New York: Handbook of Services Marketing, Carole A. Congram and Margaret L. Friedman, eds., AMACOM

Greene, W., Wallis, G. and Schrest, L. (1994) Internal Marketing The Key to External Marketing Success. Journal of Services Marketing, 8(4), pp. 5-13.

Gronroos, C. 1990. Relationship Approach to Marketing in Service Contexts: The Marketing and Organisational Behaviour Interface. Journal of Business Research, no.20, vl.5 :pp 3-11.

Gronroos, C. 1996. Relationship marketing logic, Asia Australia Marketing Journal, 4: 7-18.

Grönroos, C., 1988. Internal Marketing: een theorie in die praktijk toegepast, Marketing van diensten, 4: 1-2. 
Gronroos. C. (1985). Internal marketing theory and practice in services marketing in a changing environment. Bkx;h, T. M. et al., (Eds.). American Marketing AsscKJation: Chicago, 41-47. Gronroos, C. (1980). Designing a long range market strategy for services. Long Range Planning, 13, 36-42

Glimore ,A,(2003) services marketing and management .London:sage publications ltd.

Heskett, J. L.; Jones, T. O.; Loveman, G. W.; Sasser, W. E. and Schlesinger, L. A. (sep 1994), "Putting the service profit chain to work", Harvard Business Review, pp. 164-74.

Hoffman, K., Turley, L. (2002). Atmospherics, service encounters and consumer decision making: An integrative perspective. Journal of Marketing Theory andPractice, Summer, 13-46.

Hogg, G., Carter, S., \& Dunne, A. (1998). Investing in people: Internal marketing and corporate culture. Journal of Marketing Management, 14, 879-895.

Hogg, C. 1996. Selling your Soul. Human resources, 96(25):88-90.

Hoppock, R. (1935). Job Satisfaction, Harper and Brothers, New York.

Ibrahim et al (2010) "The Effect of Internal Marketing Implementation on Job Satisfaction of Sales People in Jordan Telecom Group". Journal of retail sector, 3 (3). 207-220.

Iliopoulos, E., \& Priporas, C. V. (2011). The effect of internal marketing on job satisfaction in health services: a pilot study in public hospitals in Northern Greece. BMC health services research, 11(1), 261.

Khaled A. Gad (2011) The Role of Internal Marketing in Job Satisfaction of Employees in the National Bank of Egypt . journal of marketing. Vol.5. No.6. pp:621-635

Kotler, P. 1991. Marketing Management - Analysis, Planning, Implementation and Control. Prentic Hall. 7th ed. NJ: Englewood Cliffs.

Kotler, P. 2000. Marketing Management: The Millennium Edition. London: Prentice-Hall

Kothari, C.R. (2004). Research methodology methods and techniques. 2nd Ed. New Delhi: New age international.

Lings, I.N. and Greenley, G.E. (2005). "Measuring internal market orientation”, Journal of Service Research, Vol. 7 No. 3, pp. 290-306

Lings , I. N. (2004) Internal market orientation construct and consequences. Journal of Business Research,Vol. 57, No. 4, pp. 405-413.

Locke, E. A. (1976). The nature and causes of job satisfaction. In M. D. Dunette (ed). Handbook of Industrial and Organizational Psychology. Rand Nally, 1297-1349.

Locke, E. A. \& Schweiger, D. M. (1979). "Participation in decision-making: One more look", Research in organizational behavior, Vol. 1 No. 10, pp. 265-339.

Maria Luiza Barcellos Zacharias, Kleber Fossati Figueiredo and Claudia Affonso Silva Araujo (2009) 'The Influence of Banking Service Customers' Satisfaction Level on the Perception of

Switching Costs and on Behavioural Loyalty' the Flagship Research Journal of International Conference of the Production and Operations Management Society, 2(1) pp 1-13

Naveed A.(2013) "The Effect of Internal Marketing on Employee retention in Pakistani Bank International Journal of Academic Research in Business and Social Sciences August 2012, Vol. 2, No. 8

Obisi, Chris (1996). "Personnel Management", Jackbod Enterprises. Ojokondo Layout Agbowo, Ibadan.

Pallant, J. (2007). SPSS Survival manual: A Step by Step Guide to Data Analysis using SPSS for Windows. 3rd edition. Berkshire, England: McGraw Hill: Open University Press.

Panigyrakis G.G and Theodoridis P.K (2009), "Internal marketing impact on business performance in a retail context" International Journal of Retail \& Distribution Management; Vol. 37 No. 7, pp. 600-628.

Peccei, R., \& Rosenthal, P. (2000). Front-line responses to customer orientation programs: A theoretical and empirical analysis. International Journal of Human Resource Management, 11 (3), 562-590.

Peltier JW, Pointer L, Schibrowsky JA. (2008). "Internal marketing and the antecedents of nurse satisfaction and loyalty”, Health Market Quart, Vol. 23 No. 4, pp. 75-108.

Peterson, M. (2003). Incorporating consumer perspectives in the architectural design of service scapes. Advances in Consumer Research, 30, 208-210.

Piercy, N. (1995). Customer satisfaction and the internal market: marketing our customers to our employees. Journal of Marketing Practice and Applied Marketing Science, vol. 1(1), 22-44.

Piercy, N. F. and Morgan, N. A. (1991). Internal marketing: the missing half of the Marketing Program. Long Range Planning, Vol.24, No.2, pp.82-93.

Rafiq, M. and Ahmed, P. K. (1998). A Customer-Oriented Framework for Empowering Service Employees. Journal of Services Marketing 12 (5): 379-94.

Rafiq, M. and Ahmed, P. K. (1993). The scope of internal marketing: defining the boundary between marketing and human resource management. Journal of Marketing Management, Vol.9, No. 3, pp. 219-232.

Rigby, D., Reichheld, F., Schefter, P. (2002). Avoid the for perils of CRM. Harvard Business Review, Feb., 101109.

Robbins, S.P. (2001). Organizational Behavior. Prentice-Hall, Upper Saddle River, NJ. 
Sasser, W.E., and Arbeit, S.P. (1980). "Selling Jobs in the Service Sector”, Business Horizons, February, pp.5859

Saunders, M. K. and Thornhill, A. (2003) Organisational justice, trust and the management of change An exploration. Personnel Review, 32(3), pp. $360-375$.

Saunders, M. K. and Thornhill, A. (2004) Trust and mistrust in organizations: An exploration using an organizational justice framework. European Journal of Work and Organizational Psychology, 13(4), pp. 493 -515 .

Saunders, M. K. and Thornhill, A. (2006) Forced employment contract change and the psychological contract. Employee Relations, 28(5), pp. 449 - 467.

Saunders, M., Lewis, P. and Thornhill, A. (2007) Research Methods for Business Students. (Fourth Edition), Harlow, England: Prentice Hall

Schlesinger, L., \& Zornitsky, J. (1991). Job satisfaction, service capability, and customer satisfaction. An examination of linkages and management implications. Human Resource Management, 14(2), 141-150.

Schneider, B., \& Bowen, D. (1999). Understanding customer delight and outrage. Sloan Management Review, Fall, 35-45.

Schuler, R., Budhwar, P. and Florkowski, G. (2002) International human resource management: review and critique. International Journal of Management Reviews, 4(1), pp. 41-70

Schultz, D. E. (2002b) Study internal marketing for better impact. Marketing News, A Publication of the American Marketing Association, October 14, pp. 8-9.

Schultz, D. E. (2004) Building an internal marketing management calculus. Interactive Marketing, 6(2), pp. 111129

Schultz, D. (2006) Definition of internal marketing remains elusive. Marketing News, A Publication of the American Marketing Association, January 15, pp. 6.

Shanka , Mesay Sata (2012). Bank Service Quality, Customer Satisfaction and Loyalty in Ethiopian Banking Sector. Journal of Business Administration and Management Sciences Research. Vol. 1:1, pp. 001-009.

Shimizu, T, Feng, L., and Nagata, S. (2005) relationship between turnover and burnout among Japanese hospital nurses. Journal of occupational health, 47 (4)334-336.

Shiu, AI and $\mathrm{Yu}, 1$. (2010). Internal marketing organizational culture, job satisfaction and organizational performance in non-life insurance. The service industry journal 30(6), 793-809

Sprietzer, G. (1995) Psychological empowerment in the workplace: Dimensions, measurement, and validation. Academy of Management Journal, 38(5), pp. 1442-1465.

Sprietzer, G. (1996) Social structural characteristics of psychological empowerment. Academy of Management Journal, 39(2), pp. 483-504.

Stauss, B. (1995) Internal services: classification and quality management. International Journal of Service Industry Management, 6(2), pp. 62-78.

Straughan, R. and Cooper, M. (2002) Managing Internal Markets: A Conceptual Framework Adapted from SERVQUAL. The Marketing Review, 2(3), pp. 253-265

Suzuki, E., Itomine, I., Kanoya, Y., Katsuki, T., Horii, S. \& Sato, C. (2006). "Factors affecting rapid turnover of novice nurses in university hospitals", Journal of Occupational Health, Vol. 48 No. 1, pp. 49-61.

Sulieman Al-Hawary, (2013). "The impact of internal marketing on employee's job satisfaction of commercial banks in Jordan", journal of contemporary research in business, vol. 37 no. 9 pp.822-832

Sulieman I.S, Kamal A.M.,Sherriah M,and Peter M.(2013). The impact of internal marketing on employees job satisfaction of commercial banks in jordan. Interdisplinary journal of contemporary research in business,vol.4, No.9, pp: 811-826.

Tadeka, F., Ibaraki, N., Yokoyama, E., Miyake, T. \& Ohida, T. (2005). "The relationship of job type to burnout in social workers at social welfare offices", Journal Occupational Health, Vol. 47 No. 2, pp. 119-125.

Tadeka, F., Ibaraki, N., Yokoyama, E., Miyake, T. \& Ohida, T. (2005), "The Relationship of Job Type to Burnout in Social Workers at Social Welfare Offices," Journal Occupational Health, Vol. 47 No. 2, pp. 119125.

Tahir .S.,Hummayoun.N.(2013). The role of in employee engagement leading to job satisfaction in pakistan private banks .journal of business management, vol. 8 No.2 pp: 62-68.

Tansuhaj, P., Randall, D., \& McCullough, J. (1991). Applying the internal marketing concept within large organizations: As applied to a credit union. Journal of Professional Services Marketing, 6(2), 193-202.

Tewahdo .T.,and Mesfin .L.(2014). The prevalence of internal marketing as a strategy implementation tool in selected Ethiopian private commercial banks . Journal of business a administration, vol.16, No. 1, pp:80114

Ting, S. C.)2010). The effect of internal marketing on organizational commitment: job involvement and job satisfaction as mediators. Educational Administration Quarterly. Vol. 5, pp 1-30.

Tourani, Azadeh \& Rast, Sadegh (2012). "Effect of Employees' Communication and Participation on 
Employees' Job Satisfaction: An Empirical Study on Airline Companies in Iran", 2nd International Conference on Economics, Trade and Development, No.4, Vol. 36.pp:12-45.

Varey, R. J.( 1995 ). "A model of internal marketing for building and sustaining a competitive service Advantage"; Journal of Marketing Management, Vol. 11, No. 1, pp. 25 - 40.

Wagner, J. A. (1994). "Participation's effects on performance and satisfaction: A reconsideration of research evidence", Academy of Management Beview, Vol. 19, pp. 312-330.

Wood, S. (1999) Human resources management and performance. International Journal of Management Reviews, 1(4), pp. 367-413.

Woodruffe, H. (1995). Service Marketing. London: Pitman

Wilson A. (1991). The internal marketing of services-the new surge, Management Decision, vol. 29(5), 4-14

Yeamdao .N. (2007). The relationship of the hotel rating system and service Quality:A case study of the 'Thailand hotels standard' Graduate College of the Oklahoma State University.

Zeithaml,V.A. and Bitner M.J,(2009). Services marketing. Integrated customer focus across the firm. 5th edition new York MC.Graw- Hill

\section{Frequency Table}

When I do something extraordinary I know that

\begin{tabular}{|ll|r|r|r|r|}
\hline & Frequency & Percent & Valid Percent & Cumulative Percent \\
\hline \multirow{4}{*}{ Valid } & 4 & 2.3 & 2.3 & 2.3 \\
& Strongly disagree & 31 & 17.5 & 17.5 & 19.8 \\
& Disagree & 20 & 11.3 & 11.3 & 31.1 \\
& Neutral & 52 & 29.4 & 29.4 & 60.5 \\
& Stree & 70 & 39.5 & 39.5 & 100.0 \\
& Total & 177 & 100.0 & 100.0 & \\
\hline
\end{tabular}

My income and the annual increases are dependent

\begin{tabular}{|ll|r|r|r|r|}
\hline & Frequency & Percent & Valid Percent & Cumulative Percent \\
\hline \multirow{6}{*}{ Valid } & Strongly disagree & 4 & 2.3 & 2.3 & 2.3 \\
& Disagree & 31 & 17.5 & 17.5 & 19.8 \\
& Neutral & 20 & 11.3 & 11.3 & 31.1 \\
& agree & 52 & 29.4 & 29.4 & 60.5 \\
& Strongly agree & 70 & 39.5 & 39.5 & 100.0 \\
& Total & 177 & 100.0 & 100.0 & \\
\hline
\end{tabular}

My income and the annual increases are very closely tied to

\begin{tabular}{|ll|r|r|r|r|}
\hline & Frequency & Percent & Valid Percent & Cumulative Percent \\
\hline \multirow{6}{*}{ Valid } & 4 & 2.3 & 2.3 & 2.3 \\
& Strongly disagree & 31 & 17.5 & 17.5 & 19.8 \\
& Disagree & 20 & 11.3 & 11.3 & 31.1 \\
& Neutral & 52 & 29.4 & 29.4 & 60.5 \\
& agree & 70 & 39.5 & 39.5 & 100.0 \\
& Strongly agree & 177 & 100.0 & 100.0 & \\
Total & & & \\
\hline
\end{tabular}

Everyone gets an annual bonus regardless of their performance

\begin{tabular}{|ll|r|r|r|r|}
\hline & Frequency & Percent & Valid Percent & Cumulative Percent \\
\hline \multirow{6}{*}{ Valid } & Strongly disagree & 4 & 2.3 & 2.3 & 2.3 \\
& Disagree & 31 & 17.5 & 17.5 & 19.8 \\
& Neutral & 20 & 11.3 & 11.3 & 31.1 \\
& agree & 52 & 29.4 & 29.4 & 60.5 \\
& Strongly agree & 70 & 39.5 & 39.5 & 100.0 \\
& Total & 177 & 100.0 & 100.0 & \\
\hline
\end{tabular}


My income and the annual increases are much related

\begin{tabular}{|ll|r|r|r|r|}
\hline & Frequency & Percent & Valid Percent & Cumulative Percent \\
\hline \multirow{6}{*}{ Valid } & Strongly disagree & 4 & 2.3 & 2.3 & 2.3 \\
& Disagree & 31 & 17.5 & 17.5 & 19.8 \\
& Neutral & 20 & 11.3 & 11.3 & 31.1 \\
& agree & 52 & 29.4 & 29.4 & 60.5 \\
& Strongly agree & 70 & 39.5 & 39.5 & 100.0 \\
& Total & 177 & 100.0 & 100.0 & \\
\hline
\end{tabular}

In this company. Training is closely related to the individual needs of each employee.

\begin{tabular}{|ll|r|r|r|r|}
\hline & Frequency & Percent & Valid Percent & Cumulative Percent \\
\hline \multirow{6}{*}{ Valid } & Strongly disagree & 8 & 4.5 & 4.5 & 4.5 \\
& Disagree & 11 & 6.2 & 6.2 & 10.7 \\
& Neutral & 37 & 20.9 & 20.9 & 31.6 \\
& agree & 63 & 35.6 & 35.6 & 67.2 \\
& Strongly agree & 58 & 32.8 & 32.8 & 100.0 \\
& Total & 177 & 100.0 & 100.0 & \\
\hline
\end{tabular}

A newly hired employee will have to find his own answers to the requirements of the job

\begin{tabular}{|ll|r|r|r|r|}
\hline & Frequency & Percent & Valid Percent & Cumulative Percent \\
\hline \multirow{6}{*}{ Valid } & 8 & 4.5 & 4.5 & 4.5 \\
& Strongly disagree & 11 & 6.2 & 6.2 & 10.7 \\
& Disagree & 37 & 20.9 & 20.9 & 31.6 \\
& Neutral & 63 & 35.6 & 35.6 & 67.2 \\
& agree & 58 & 32.8 & 32.8 & 100.0 \\
& Strongly agree & 177 & 100.0 & 100.0 & \\
Total & & & \\
\hline
\end{tabular}

Before the implementation of a major change in service rules we always get significant training regarding its

\begin{tabular}{|ll|r|r|r|r|}
\hline \multicolumn{5}{|c|}{ impact on our daily activities and job description } \\
\hline \multirow{6}{*}{ Valid } & Frequency & Percent & Valid Percent & Cumulative Percent \\
& Strongly disagree & 8 & 4.5 & 4.5 & 4.5 \\
& Disagree & 11 & 6.2 & 6.2 & 10.7 \\
& Neutral & 37 & 20.9 & 20.9 & 31.6 \\
& agree & 63 & 35.6 & 35.6 & 67.2 \\
& Strongly agree & 58 & 32.8 & 32.8 & 100.0 \\
Total & 177 & 100.0 & 100.0 & \\
\hline
\end{tabular}

If one is moved from one department to another, the new supervisor will personally train him/her for a prespecified period of time

\begin{tabular}{|ll|r|r|r|r|}
\hline & Frequency & Percent & Valid Percent & Cumulative Percent \\
\hline \multirow{6}{*}{ Valid } & Strongly disagree & 8 & 4.5 & 4.5 & 4.5 \\
& Disagree & 11 & 6.2 & 6.2 & 10.7 \\
& Neutral & 37 & 20.9 & 20.9 & 31.6 \\
& agree & 63 & 35.6 & 35.6 & 67.2 \\
& Strongly agree & 58 & 32.8 & 32.8 & 100.0 \\
& Total & 177 & 100.0 & 100.0 & \\
\hline
\end{tabular}


In this company. They set aside adequate resources to train employees

\begin{tabular}{|ll|r|r|r|r|}
\hline & Frequency & Percent & Valid Percent & Cumulative Percent \\
\hline \multirow{6}{*}{ Valid } & Strongly disagree & 8 & 4.5 & 4.5 & 4.5 \\
& Disagree & 11 & 6.2 & 6.2 & 10.7 \\
& Neutral & 37 & 20.9 & 20.9 & 31.6 \\
& agree & 63 & 35.6 & 35.6 & 67.2 \\
& Strongly agree & 58 & 32.8 & 32.8 & 100.0 \\
& Total & 177 & 100.0 & 100.0 & \\
\hline
\end{tabular}

Training and development programme is clearly directed at creating the competencies that are important to our

\begin{tabular}{|c|c|c|c|c|c|}
\hline \multicolumn{6}{|c|}{ business } \\
\hline & & Frequency & Percent & Valid Percent & Cumulative Percent \\
\hline \multirow{6}{*}{ Valid } & Strongly disagree & 8 & 4.5 & 4.5 & 4.5 \\
\hline & Disagree & 11 & 6.2 & 6.2 & 10.7 \\
\hline & Neutral & 37 & 20.9 & 20.9 & 31.6 \\
\hline & agree & 63 & 35.6 & 35.6 & 67.2 \\
\hline & Strongly agree & 58 & 32.8 & 32.8 & 100.0 \\
\hline & Total & 177 & 100.0 & 100.0 & \\
\hline
\end{tabular}

Before any policy change my supervisor informs me phase-to-phase in advance

\begin{tabular}{|ll|r|r|r|r|}
\hline & Frequency & Percent & Valid Percent & Cumulative Percent \\
\hline \multirow{6}{*}{ Valid } & Strongly disagree & 16 & 9.0 & 9.0 & 9.0 \\
& Disagree & 34 & 19.2 & 19.2 & 28.2 \\
& Neutral & 101 & 57.1 & 57.1 & 85.3 \\
& agree & 26 & 14.7 & 14.7 & 100.0 \\
& Total & 177 & 100.0 & 100.0 & \\
\hline
\end{tabular}

Supervisors are sincerely interested in listening to what subordinates have to say about their jobs, the problems they have and the solutions that subordinates suggest

\begin{tabular}{|ll|r|r|r|r|}
\hline & Frequency & Percent & Valid Percent & Cumulative Percent \\
\hline \multirow{6}{*}{ Valid } & Strongly disagree & 16 & 9.0 & 9.0 & 9.0 \\
& Disagree & 34 & 19.2 & 19.2 & 28.2 \\
& Neutral & 101 & 57.1 & 57.1 & 85.3 \\
& agree & 26 & 14.7 & 14.7 & 100.0 \\
& Total & 177 & 100.0 & 100.0 & \\
\hline
\end{tabular}

If an employee has a certain personal problem that influences negatively his (her) work performance, (s)he is encouraged to discuss it with his/her supervisor

\begin{tabular}{|ll|r|r|r|r|}
\hline & Frequency & Percent & Valid Percent & Cumulative Percent \\
\hline \multirow{6}{*}{ Valid } & Strongly disagree & 16 & 9.0 & 9.0 & 9.0 \\
& Disagree & 34 & 19.2 & 19.2 & 28.2 \\
& Neutral & 101 & 57.1 & 57.1 & 85.3 \\
& agree & 26 & 14.7 & 14.7 & 100.0 \\
& Total & 177 & 100.0 & 100.0 & \\
\hline
\end{tabular}


Supervisors in this company are

never too busy if one of their subordinate wishes to meet personally

\begin{tabular}{|ll|r|r|r|r|}
\hline & Frequency & Percent & Valid Percent & Cumulative Percent \\
\hline \multirow{4}{*}{ Valid } & Strongly disagree & 16 & 9.0 & 9.0 & 9.0 \\
& Disagree & 34 & 19.2 & 19.2 & 28.2 \\
& Neutral & 101 & 57.1 & 57.1 & 85.3 \\
& agree & 26 & 14.7 & 14.7 & 100.0 \\
& Total & 177 & 100.0 & 100.0 & \\
\hline
\end{tabular}

Supervisors are expected to spend time with their subordinates, explaining them company objectives and how these objectives affect what the company expects from each individual employee

\begin{tabular}{|ll|r|r|r|r|}
\hline & Frequency & Percent & Valid Percent & Cumulative Percent \\
\hline \multirow{6}{*}{ Valid } & Strongly disagree & 16 & 9.0 & 9.0 & 9.0 \\
& Disagree & 34 & 19.2 & 19.2 & 28.2 \\
& Neutral & 101 & 57.1 & 57.1 & 85.3 \\
& agree & 26 & 14.7 & 14.7 & 100.0 \\
& Total & 177 & 100.0 & 100.0 & \\
\hline
\end{tabular}

My supervisor allows me to use my own judgment in solving problems

\begin{tabular}{|ll|r|r|r|r|}
\hline & Frequency & Percent & Valid Percent & Cumulative Percent \\
\hline \multirow{6}{*}{ Valid } & 11 & 6.2 & 6.2 & 6.2 \\
& Strongly disagree & 77 & 43.5 & 43.5 & 49.7 \\
& Disagree & 63 & 35.6 & 35.6 & 85.3 \\
& Neutral & 22 & 12.4 & 12.4 & 97.7 \\
& agree & 4 & 2.3 & 100.0 \\
& Strongly agree & 177 & 100.0 & 100.0 & \\
Total & & & \\
\hline
\end{tabular}

My supervisor encourages me to take initiatives

\begin{tabular}{|ll|r|r|r|r|}
\hline & Frequency & Percent & Valid Percent & Cumulative Percent \\
\hline \multirow{6}{*}{ Valid } & 11 & 6.2 & 6.2 & 6.2 \\
& Strongly disagree & 77 & 43.5 & 43.5 & 49.7 \\
& Nisagree & 63 & 35.6 & 35.6 & 85.3 \\
& Neutral & 22 & 12.4 & 12.4 & 97.7 \\
& Stroe & 4 & 2.3 & 2.3 & 100.0 \\
& Total & 177 & 100.0 & 100.0 & \\
\hline
\end{tabular}

My supervisor allows me a high degree of initiative

\begin{tabular}{|ll|r|r|r|r|}
\hline & Frequency & Percent & Valid Percent & Cumulative Percent \\
\hline \multirow{6}{*}{ Valid } & 11 & 6.2 & 6.2 & 6.2 \\
& Strongly disagree & 77 & 43.5 & 43.5 & 49.7 \\
& Disagree & 63 & 35.6 & 35.6 & 85.3 \\
& Neutral & 22 & 12.4 & 12.4 & 97.7 \\
& agree & 2.3 & 2.3 & 100.0 \\
& Strongly agree & 4 & 100.0 & \\
Total & 177 & 100.0 & 100.3 \\
\hline
\end{tabular}


My supervisor trusts me to exercise good Judgment

\begin{tabular}{|ll|r|r|r|r|}
\hline & Frequency & Percent & Valid Percent & Cumulative Percent \\
\hline \multirow{6}{*}{ Valid } & 11 & 6.2 & 6.2 & 6.2 \\
& Strongly disagree & 77 & 43.5 & 43.5 & 49.7 \\
& Disagree & 63 & 35.6 & 35.6 & 85.3 \\
& Neutral & 22 & 12.4 & 12.4 & 97.7 \\
& Stree & 4 & 2.3 & 2.3 & 100.0 \\
& Total & 177 & 100.0 & 100.0 & \\
\hline
\end{tabular}

I am positive about my job

\begin{tabular}{|ll|r|r|r|r|}
\hline & Frequency & Percent & Valid Percent & Cumulative Percent \\
\hline \multirow{6}{*}{ Valid } & Strongly disagree & 24 & 13.6 & 13.6 & 13.6 \\
& Disagree & 60 & 33.9 & 33.9 & 47.5 \\
& Neutral & 60 & 33.9 & 33.9 & 81.4 \\
& agree & 33 & 18.6 & 18.6 & 100.0 \\
& Total & 177 & 100.0 & 100.0 & \\
\hline
\end{tabular}

I have a positive feelings towards the bank and the work

\begin{tabular}{|ll|r|r|r|r|}
\hline & Frequency & Percent & Valid Percent & Cumulative Percent \\
\hline \multirow{6}{*}{ Valid } & Strongly disagree & 24 & 13.6 & 13.6 & 13.6 \\
& Disagree & 60 & 33.9 & 33.9 & 47.5 \\
& Neutral & 60 & 33.9 & 33.9 & 81.4 \\
& agree & 33 & 18.6 & 18.6 & 100.0 \\
& Total & 177 & 100.0 & 100.0 & \\
\hline
\end{tabular}

I am satisfied with the responsibility and role that I have in my work

\begin{tabular}{|ll|r|r|r|r|}
\hline & Frequency & Percent & Valid Percent & Cumulative Percent \\
\hline \multirow{4}{*}{ Valid } & Strongly disagree & 24 & 13.6 & 13.6 & 13.6 \\
& Disagree & 60 & 33.9 & 33.9 & 47.5 \\
& Neutral & 60 & 33.9 & 33.9 & 81.4 \\
& agree & 33 & 18.6 & 18.6 & 100.0 \\
& Total & 177 & 100.0 & 100.0 & \\
\hline
\end{tabular}

I am satisfied with the support from the HR department

\begin{tabular}{|ll|r|r|r|r|}
\hline & Frequency & Percent & Valid Percent & Cumulative Percent \\
\hline \multirow{6}{*}{ Valid } & Strongly disagree & 24 & 13.6 & 13.6 & 13.6 \\
& Disagree & 60 & 33.9 & 33.9 & 47.5 \\
& Neutral & 60 & 33.9 & 33.9 & 81.4 \\
& agree & 33 & 18.6 & 18.6 & 100.0 \\
& Total & 177 & 100.0 & 100.0 & \\
\hline
\end{tabular}

I generally like to schedule my own work and to make job-related decisions with a minimum of supervision

\begin{tabular}{|ll|r|r|r|r|}
\hline & Frequency & Percent & Valid Percent & Cumulative Percent \\
\hline \multirow{6}{*}{ Valid } & Strongly disagree & 24 & 13.6 & 13.6 & 13.6 \\
& Disagree & 60 & 33.9 & 33.9 & 47.5 \\
& Neutral & 60 & 33.9 & 33.9 & 81.4 \\
& agree & 33 & 18.6 & 18.6 & 100.0 \\
& Total & 177 & 100.0 & 100.0 & \\
\hline
\end{tabular}


I will recommend for working in this bank for others

\begin{tabular}{|ll|r|r|r|r|}
\hline & Frequency & Percent & Valid Percent & Cumulative Percent \\
\hline \multirow{6}{*}{ Valid } & Strongly disagree & 24 & 13.6 & 13.6 & 13.6 \\
& Disagree & 60 & 33.9 & 33.9 & 47.5 \\
& Neutral & 60 & 33.9 & 33.9 & 81.4 \\
& agree & 33 & 18.6 & 18.6 & 100.0 \\
& Total & 177 & 100.0 & 100.0 & \\
\hline
\end{tabular}

I am satisfied with the banks policies

\begin{tabular}{|ll|r|r|r|r|}
\hline & Frequency & Percent & Valid Percent & Cumulative Percent \\
\hline \multirow{6}{*}{ Valid } & Strongly disagree & 24 & 13.6 & 13.6 & 13.6 \\
& Disagree & 60 & 33.9 & 33.9 & 47.5 \\
& Neutral & 60 & 33.9 & 33.9 & 81.4 \\
& agree & 33 & 18.6 & 18.6 & 100.0 \\
& Total & 177 & 100.0 & 100.0 & \\
\hline
\end{tabular}

I feel that the job I do gives me a good status.

\begin{tabular}{|rl|r|r|r|r|}
\hline & Frequency & Percent & Valid Percent & Cumulative Percent \\
\hline \multirow{6}{*}{ Valid } & Strongly disagree & 24 & 13.6 & 13.6 & 13.6 \\
& Disagree & 60 & 33.9 & 33.9 & 47.5 \\
& Neutral & 60 & 33.9 & 33.9 & 81.4 \\
& agree & 33 & 18.6 & 18.6 & 100.0 \\
& Total & 177 & 100.0 & 100.0 & \\
\hline
\end{tabular}

I feel satisfied with the job I am doing for my bank

\begin{tabular}{|ll|r|r|r|r|}
\hline & Frequency & Percent & Valid Percent & Cumulative Percent \\
\hline \multirow{6}{*}{ Valid } & Strongly disagree & 24 & 13.6 & 13.6 & 13.6 \\
& Disagree & 60 & 33.9 & 33.9 & 47.5 \\
& Neutral & 60 & 33.9 & 33.9 & 81.4 \\
& agree & 33 & 18.6 & 18.6 & 100.0 \\
& Total & 177 & 100.0 & 100.0 & \\
\hline
\end{tabular}

